\title{
Invandrarnas yrkesutbildning och sysselsättning i Finland
}

\section{(Immigrants' vocational education and employment in Finland)}

\author{
Johanna Lasonen \\ University of South Florida, USA (lasonen@usf.edu) \\ Marianne Teräs
}

Stockholms universitet, Sverige

Carine Cools

University of Jyväskylä, Finland

\begin{abstract}
In Finland, immigration has increased in recent decades. An equal quality of life and position for immigrants is a vocational and social challenge. In our article, we examine the challenges adult immigrants face in Finland regarding the recognition of professional qualifications, skills and employment and their children's access to education. As a result, we have two different points of view: adults in working life and young people in school transitions. The research materials were collected through interviews and surveys. The results suggest that adult immigrants usually have their skills recognised in the labour market only when the person obtains an overlapping or supplementary vocational training in Finland. Adolescents' school transitions are tied to at least three types of factors: the young people themselves, issues related to the community, and services offered by society. The authorities reiterated the importance of language skills, the motivation, and community services, while the young people promoted the social community: the importance of friends and families. The results highlight the importance of cooperation between the authorities, homes and young people so that young people can receive support at special stages in their lives.
\end{abstract}

Keywords: immigration, recognition, vocational education, employment, transition

Peer-reviewed article doi: 10.3384/njvet.2242-458X.20103138 


\section{Inledning}

Invandringen till Finland har stabiliserats under de tre senaste årtiondena. För närvarande kommer majoriteten av invandrarna från länder utanför den Europeiska unionen. De främsta motiven för att komma till Finland har sedan 1970talet varit flyktingskap och sedan 1990-talet familjeband. Först från och med cirka år 2000 har orsaken till invandring utökats med arbete i Finland. I allmän statistik används även benämningen utlänningar om invandrare. Vid uppskattning av antalet utlänningar används en persons medborgarskap eller modersmål, vilket givetvis ger olika antal. När en persons medborgarskap används som grund för beräkningen finns inte den som har fått finländskt medborgarskap längre med i statistiken. I befolkningsstatistiken avses med främmandespråkiga sådana personer som har ett annat modersmål än finska, svenska eller samiska. Enligt Statistikcentralen (2020) bodde cirka 424000 främmandespråkiga personer i Finland, vilket är 7,5 procent av hela befolkningen. Personer som talar ryska, estländska och somaliska är de tre största grupperna i Finland.

Den allmänna tendensen i Europa är att invandrare proportionellt har en högre arbetslöshetsgrad än den infödda befolkningen.

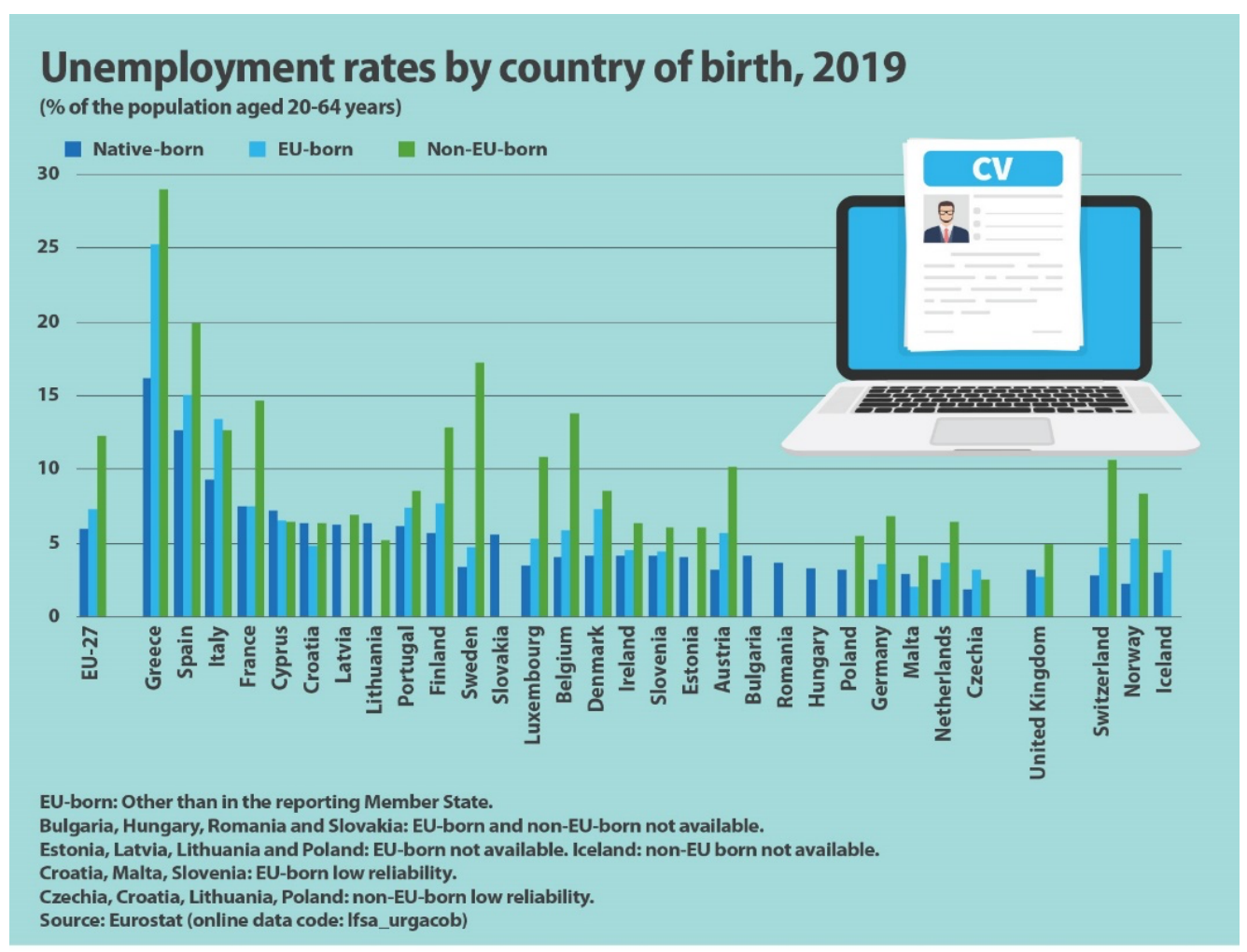

ec.europa.eu/eurostat.

Bild 1. Total arbetslöshet $i$ EU-27 och arbetslösheten bland medborgare från övriga EUländer och från utomeuropeiska länder (Eurostat, 2020a). 
Så är fallet även i Finland. I Europa år 2019 kan ett högre procenttal arbetslösa bland invandrare noteras, 12,3 procent, jämfört med 6 procent bland infödda medborgare (Eurostat, 2020a). Bild 1 beskriver invandrares arbetslöshet jämfört med total arbetslöshet i respektive medlemsstater i den Europeiska unionen. Invandrarnas sysselsättningssiffror behöver inte nödvändigtvis innebära att deras kunskapsnivå var lägre jämfört med den inhemska befolkningen. Många invandrare har avlagt flera examina både i ursprungslandet och i värdlandet. Trots detta måste många börja sitt liv i Finland med att gå till yrkesskolor för att få sina kompetenser erkända och för att studera finska språket.

Med medborgare från tredjeland avses personer som kommer från ett land utanför den Europeiska unionen (EU). Enligt bild 1 är arbetslösheten bland medborgare från tredjeland i nästan alla EU-länder mycket högre än i värdländerna. Genomsnittet i 27 EU-länder avslöjar att invandrarnas arbetslöshet är mer än dubbelt så hög jämfört med de som är födda i EU-värdländerna.

Historiskt sett har kvinnor påverkats mer av arbetslöshet än män (Eurostat, 2020b). Dessutom är det i de flesta OECD-länder (Organisationen för ekonomiskt samarbete och utveckling) svårare för invandrarkvinnor att hitta arbete än det är för invandrarmän, och det är svårare för invandrarkvinnor att hitta arbete än det är för infödda kvinnor. Exempelvis är det nästan lika sannolikt för infödda finländska kvinnor att ha arbete som det är för infödda finländska män, men det är mindre sannolikt att utlandsfödda finländska kvinnor arbetar än det är för utlandsfödda finländska män (International Migration Outlook, 2013; Lasonen, 2009; Lasonen m.fl., 2011). Erkännandet av invandrares tidigare kompetenser är högst varierande och många gånger måste yrkesutbildade personer börja om sina studier från början (se Lasonen m.fl., 2011; Schuster m.fl., 2013). Dessutom är det för invandrarna ett hinder att de inte talar och förstår det finska språket tillräckligt bra när de söker arbete.

Finlands lag om främjande av integration (Justitieministeriet 1386/2010) trädde i kraft den 1 september 2011. Det primära målet med integrationen av vuxna invandrare är att stödja erkännande av deras kompetenser och sysselsättning på den öppna arbetsmarknaden. Invandrarnas höga arbetslöshetsgrad (nästan tre gånger högre än majoritetsbefolkningens) kommer att sänkas t.ex. genom stöd för anställning av invandrare via integrerad sysselsättning och företagsamhetstjänster vid arbets- och näringsbyråns förvaltning samt genom stärkt internationaliseringskompetens på arbetsmarknaden.

Möjligheterna för unga finländska medborgare med invandringsbakgrund att avancera i yrkesutbildning och arbetsliv har varit föremål för granskning. Ruotsalainen och Nieminen (2012) framför att det i Finland fanns cirka 260000 personer år 2011 vars båda föräldrar var födda utomlands. Av dem var 38000 själva födda i Finland (s.k. generation 2), och för cirka 113000 personer var en av föräldrarna född i utlandet (s.k. generation 2,5). Med den första generationens invandrare avses personer som har flyttat som vuxna till ett nytt land och med den 
andra generationen deras barn som är födda i destinationslandet. Den amerikanske invandringsforskaren Rumbaut (2007) förde in begreppet mellangeneration i diskussionen eftersom han ansåg att indelningen i första och andra generationen är alltför grov. Han menar att särskilt ett barns ålder vid invandring samt barnets och föräldrarnas födelseland har betydelse för barnets situation.

Till exempel i Helsingfors, där majoriteten av invandrade är koncentrerad, förutspås antalet 7-15-åringar med ett främmande språk som modersmål öka till knappt 10000 år 2020 och till 13800 år 2030, vilket innebär att andelen av hela åldersklassen ökar från 15 procent år 2012 till 23 procent år 2030 (Helsingfors stads faktacentral, 2013, s. 19). I artikeln använder vi begreppen olika språk- och kulturbakgrund och invandringsbakgrund i stället för invandrarbakgrund, eftersom begreppet när det handlar om barn och ungdomar bättre täcker att en person inte nödvändigtvis själv har flyttat till landet, men invandring har i regel generationsöverskridande följder som ses i barnens och ungdomarnas liv (se Martikainen m.fl., 2013).

År 2010 studerade cirka 75 procent av alla 16-24-åringar i en skola efter den grundläggande utbildningen. Av första generationens invandrare studerade något över 50 procent och av andra generationens invandrare 68 procent (Ruotsalainen \& Nieminen, 2012). Medan 5,5 procent av majoritetsbefolkningens ungdomar lät bli att söka till utbildning i gymnasium eller yrkesskola, gjorde 15,4 procent likadant av första generationens invandrare från länder utanför EU (Kuusela m.fl., 2008). Det finns även stora skillnader i antalet antagna till utbildning (Kilpinen \& Salonen, 2011). Den första generationens ungdomar från länder utanför EU verkar befinna sig i en särskilt riskbenägen situation. För flickor gäller risken skolövergången, medan risken för pojkar verkar gälla avbrytande av utbildning i gymnasium och särskilt i yrkesutbildning (Kuusela m.fl., 2008). Å andra sidan visar Kilpi-Jakonens (t.ex. Kilpi, 2010; se även Heath m.fl., 2008) undersökningar att studieframgången för andra generationens ungdomar knappast alls skiljer sig från studieframgången för majoritetsbefolkningens ungdomar. Den bakgrundsfaktor som starkast påverkar studieframgången är föräldrarnas socioekonomiska bakgrund. Den andra generationen är också villigare att fortsätta i gymnasiet än $i$ ett yrkesinstitut och till exempel elever av östasiatiskt ursprung har störst framgång i utbildningen. Dessutom påpekar Kilpi-Jakonen att skillnaderna inom grupperna gällande skolframgång är avsevärt större än skillnaderna mellan dem (Kilpi, 2010; se även Teräs \& Kilpi-Jakonen, 2013.) Detta flyttar fokus från åtgärder som stödjer den enskilda elevens framgång i skolövergången till familjens situation mer allmänt samt till föräldrarnas sysselsättning och integration.

Syftet med denna artikel är att utreda hur vuxna personer med invandringsbakgrund såg på sin karriärutveckling och sina sysselsättningsmöjligheter i Finland. Därefter undersökte vi vilka utmaningar deras barn, dvs. andra generationens ungdomar själva, och personer som arbetar med ungdomarna, rapporterar vid övergången från grundläggande utbildning till utbildning på andra stadiet. I 
Finland betyder det att de unga måste välja mellan gymnasium och yrkesutbildning. Undersökningens teoretiska bakgrund baserar sig på teorin om kritisk socialvetenskap där det centrala begreppet är erkännande.

\section{Erkännande av kompetens}

Erkännande som ett samhällsfenomen har studerats av akademiker som representerar den kritiska teorin, exempelvis Axel Honneth och Nancy Fraser. Identitet, självdefinition och erkännande har sammankopplats med kampen för värdighet, respekt och självbestämmanderätt. Honneth och Charles Taylor, som har gjort sig en föreställning om teorierna kring erkännandets mångkulturella politik, betonar att individer behöver medlemskap i sociala grupper som erkänner deras särprägel, rättigheter och resurser. Enligt Taylor (1994) har mänskligt liv en dialogisk natur och är förenat med allmänt erkännande av etniska, religiösa och nationella grupper. Identiteter ändras, bejakas och utvecklas. Honneth (1992) antyder att erkännande kräver ett visst mått av "social acceptans av en individs personliga utveckling inom de kulturella traditionerna i ett givet samhälle" (s. 191). Fraser (1997) går längre och säger att social rättvisa debatteras när ett samhälles "dominerande kulturmönster för tolkning och värdering" (s. 39) orättvist etablerar de sociala grunderna för självrespekt för olika sociala grupper. Fraser (1997) betonar en grundläggande oenighet mellan en "kulturell rättviseteori" som ökar erkännandet av olikhet och en "teori för rättvis fördelning" som förespråkar rättvis fördelning av resurser (s. 6).

Social respekt speglas i kraven på och skapandet av lika möjligheter också för minoriteter så att deras olika förutsättningar - dvs. vad beträffar språk, religion, etnisk bakgrund och klasstillhörighet - tas i beaktande. Respekt och erkännande är nödvändigt för socialiseringsprocessen och identitetsbildningen under hela livstiden. Idén i Honneths $(1992,1995)$ normativa erkännandeteori är att skapa en personlig identitet och att utvecklas som person. Psykologiska resurser är självtillit, självrespekt och självaktning som bildas i interaktion med omgivningen. Social respekt bygger på erkännandemönster i relation till dessa aspekter. Det är sårande när erkännande nekas eftersom det skadar subjekten och begränsar deras frihet att agera och förstå sig själva. Honneths synsätt innehåller även ett normativt ideal eftersom han påstår att erkännande inte bara handlar om abstrakt rättvisa och jämlikhet, utan också om personlig utveckling, en överenskommen mental atmosfär i en viss livsvärld och "ett bra liv" (Honneth, 1995, s. 172).

Omfördelning (redistribution) är ett koncept som används av Fraser. Hon påstår att dagens sociala kamp för omfördelning är ett lika centralt koncept som erkännande (Fraser, 1997). Fraser stöder en analytisk skillnad mellan ekonomi och kultur eller klass och status, en skillnad mellan den ekonomiska kampen för jämlik fördelning och den kulturella kampen för erkännande. Ett kapitalistiskt 
samhälle omfattar både en systematiskt integrerad marknadsordning och en värderingsstyrd social ordning, vilket innebär att man skiljer mellan systemintegration och social integration (Fraser, 1997). Marknadsordningen karaktäriseras av en kamp för materialistiska fördelar, medan människor kämpar om högre status i den sociala ordningen. Fraser argumenterar för "proportionell dualism" som ett verktyg för systemanalyser och relevanta distinktioner. Samma sociala kamp kan faktiskt ses å ena sidan som en kamp för fördelningen av välfärd och å andra sidan som en kamp för erkännande.

Erkännande är en väsentlig aspekt av social rättvisa och för med sig moralisk integration (Honneth, 1995, 2004). Enligt Fraser (1997) skapar rättvis fördelning av materiella resurser vid sidan av erkännande också social rättvisa. Erkännande och omfördelning är lika viktiga grundelement som kompletterar varandra. Erkännande är också en förutsättning för social interaktion och gäller mer än bara empatiska ord och gester (Honneth, 1995). Det är ett vitalt mänskligt behov enligt Taylor (1994). Av denna orsak räcker det inte att uttrycka erkännande bara genom att vara hänsynsfull eller artig eller tolerant mot olika människor. Erkännande är en förutsättning såväl för att skapa en personlig identitet som för att utvecklas som person. Fraser (1997) förknippar erkännande med både omfördelning och status, eftersom de som inte har fått erkännande blir sämre lottade och sämre respekterade i sociala system. Taylor (1994) binder erkännande till multikulturalism. Människor får i allmänhet uppmärksamhet för att de på ett positivt sätt särskiljer sig från andra, särskilt på grund av deras speciella kulturella särdrag. Taylor definierar två typer av erkännande: jämlik mänsklig värdighet som en form av demokrati och erkännandet av andra personer för deras unika karaktär och identitet. Unik karaktär är en drivkraft i utvecklingen av individer och samhällen.

En kvalificerad person har det formella resultatet i form av en examen eller ett betyg från ett annat land eller värdlandet. Enligt CEDEFOP (2008) "tilldelas [en] kvalifikation officiellt erkännande av inlärningsresultatens värde på arbetsmarknaden och inom utbildning och praktik. Kvalifikation kan vara en laglig rättighet att utöva en näring" (s. 144). Kvalifikationerna gäller som kompetens i vissa sammanhang som kan vara arbetssituationer, utbildnings- och studiemiljöer eller personlig utveckling. Kompetensen är en persons helhetsmässiga särdrag och består av färdigheter, personlighet, attityder och kunskaper. Många invandrare har formella utbildningar och kvalifikationer när de flyttar från ett land till ett annat. Men erkännandet av deras kompetens i ett nytt land är en utmaning.

På praktisk nivå gäller erkännande av kompetens de mått vi använder för att ta reda på, beräkna och jämföra kvalifikationer och kompetens som har skaffats $i$ ett annat land och att jämföra dem med motsvarande krav i destinationslandet. När detta leder till erkännande och godkännande som motsvarande nationella kvalifikationer kan vi tala om formellt erkännande av kvalifikationer. Detta ga- 
ranterar emellertid inte att en arbetsgivare erkänner personen och dennes kvalifikationer på jämlik grund på arbetsplatsen. Formellt erkännande av en invandrares tidigare utbildning och kvalifikationer regleras av Utbildningsstyrelsen och Tillstånds- och tillsynsverket för social- och hälsovården (Valvira). För yrkesmässiga kvalifikationer kan beslut om erkännande fattas av Utbildningsstyrelsen, en branschspecifik myndighet eller en arbetsgivare. Utbildningsstyrelsen beslutar om utländska kvalifikationer ger berättigande till vissa befattningar inom den offentliga sektorn, medan branschspecifika myndigheter ger tillstånd att utöva vissa näringar och yrken och Valvira beviljar efter ansökan tillstånd att utöva hälso- och sjukvårdsyrken i Finland. Arbetsgivare inom den privata sektorn utvärderar vanligen kvalifikationer och kompetens själva. Beslut om akademiskt erkännande fattas av berörda utbildningsinstitut, t.ex. om kurspoäng för utländska studier och vilken behörighet till fortsatta studier dessa kan ge. En undersökning av Jaakkola och Reuter (2007) om sysselsättningen hos invandrarkvinnor från det forna Sovjetunionen visade att inte ens en högskolexamen avlagd i ursprungslandet garanterade sysselsättning. Däremot underlättades anställning av en utbildning som skaffats i Finland. En universitetsexamen från ursprungslandet verkade vara till störst nytta för de kvinnor som hade bott i Finland längre än 10 år. Inom vissa branscher kan yrkesutbildade personer visserligen få arbete genast efter att de har anlänt till det nya landet (t.ex. inom informationsteknologi och tidigare toppmusiker) (Lasonen, 2010).

\section{Undersökningsprocedurer}

Undersökningsmaterialet består av intervjuer med första generationens vuxna invandrare och frågor $\mathrm{i}$ en enkät som har strukturerats utifrån deras svar och syftar till att få exakt information om yrkesutbildning, arbetsår, sysselsättningsperioder osv. I de individuella intervjuerna deltog 86 personer varav 57 även returnerade enkäten. Största delen av dem hade bott i Finland 8-18 år och kom vid undersökningstillfället från olika håll i Finland. Intervjuerna varade 90-120 minuter och spelades in samt transkriberades för en kvalitativ analys. Dessutom bestod materialet med unga, andra generationens invandrare av 10 individuella intervjuer samt enkätsvar från 20 myndighetsrepresentanter, av dessa intervjuades nio även individuellt. Intervjupersonerna arbetade som lärare och studiehandledare i yrkesskolor och i den grundläggande utbildningen, som handledare inom utbildning av workshoptyp och inom stadens undervisningsförvaltning. De intervjuade ungdomarna studerade inom förberedande eller egentlig yrkesutbildning. Materialet som gäller ungdomar har samlats in i Helsingforsregionen där migrationen är koncentrerad. De intervjuade ungdomarnas ålder varierade mellan 17 och 22 år. Av dem var hälften flickor och hälften pojkar. Åtta ungdomar studerade inom vägledande och förberedande yrkesutbildning, en arbetade 
och en studerade vid universitet när intervjun gjordes. Deras föräldrar hade flyttat till Finland från länder i Asien och Afrika samt från Ryssland.

Enkät- och intervjumaterialet analyserades med induktiv tematisk analys (Braun \& Clarke, 2006; Guest m.fl., 2012), och dessutom användes programmet Atlas.ti 6.2 som lämpar sig för kvalitativt material. Tematisk analys är en iterativ analysmetod. Den började med att identifiera koder och temaområden och avancerade med att precisera och benämna teman. Till sist gjorde vi en temabaserad modellering av faktorerna för erkännande, sysselsättning och utbildningsövergång: en temakarta som vi använde till att identifiera utmaningarnas förhållanden till varandra (Figur 1). Den tematiska analysen gav koncentrerad information om materialet. Som analytiska begrepp använde vi det teoretiska begreppet för erkännande och övergångsfaktorn.

Det fanns över tusen sidor med transkriberat intervjumaterial. Temana i figuren återger de vanligaste omständigheterna som både de vuxna och de unga vuxna framförde.

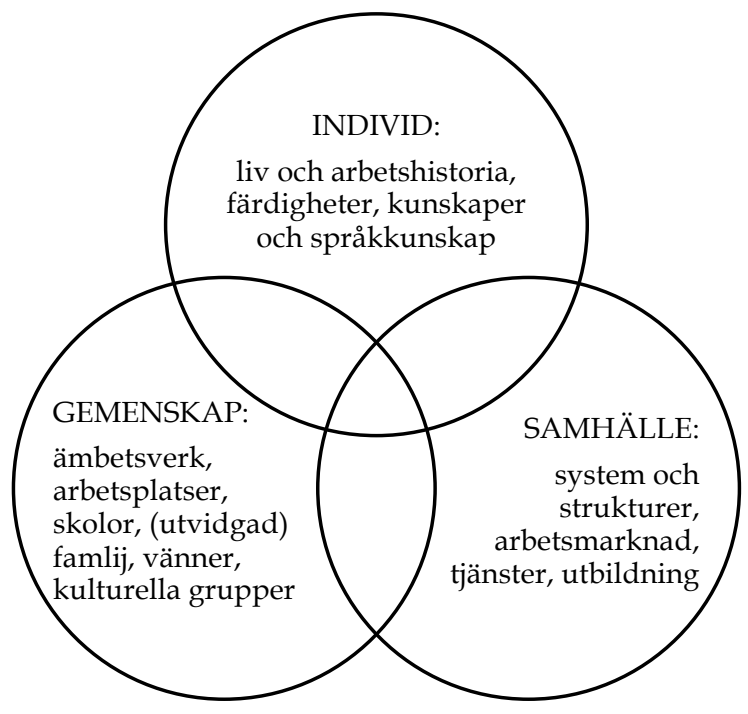

Figur 1. Temakarta över erkännande och övergångar för vuxna och unga personer med invandringsbakgrund.

\section{Sysselsättning och erkännande av kompetens gällande vuxna invandrare}

Av de vuxna enkätdeltagarna som var födda på annat håll hade över hälften bott 8-18 år i Finland. Nästan hälften av enkätdeltagarna hade en examen på eftergymnasial nivå, en fjärdedel examen från yrkesskola eller yrkesinstitut och en av tio avgångsbetyg från gymnasium eller grundskola. Förutom att de hade hög utbildningsnivå var enkätdeltagarna flerspråkiga. Var fjärde kunde två eller fyra språk och hela 44 procent behärskade tre språk muntligt och skriftligt. Varannan 
enkätdeltagares tidigare examen var officiellt jämställd i Finland. Hälften av enkätdeltagarna hade inte fått arbete motsvarande sin utbildning och kompetens i Finland och en tredjedel hade även skolat om sig i Finland. Den populäraste formen för omskolning var yrkesinriktat mellanstadium eller yrkeshögskoleexamen. En tredjedel av deltagarna hade studerat under hela tiden de hade bott i Finland. Av de arbetslösa invandrarna var hälften långtidsarbetslösa. Av enkätdeltagarna var 14 procent arbetslösa, cirka 17 procent arbetade deltid och nästan 37 procent arbetade heltid. Cirka 21 procent av deltagarna studerade. Var tionde besvarade inte frågan och en procent svarade att de var hemmamammor. Enkätdeltagarna hade sökt arbete både via arbets- och näringsbyrån och sina praktikantplatser. Endast fyra av tio hade blivit erbjudna arbete som motsvarar utbildningen. Mest hade invandrarnas ändrade karriärplaner påverkats av det dåliga arbetsmarknadsläget, de egna kunskaperna och färdigheterna samt kunskaperna i finska språket. En tredjedel av enkätdeltagarna ansåg det möjligt att grunda ett eget företag för att sysselsätta sig, men största delen hade inte ens övervägt detta. Cirka en tredjedel av deltagarna ansåg att de i mycket liten grad kan påverka framtidsutsikterna för sin karriär. En tredjedel hade fortfarande oklara planer om hur de skulle få arbete. Alla intervjuade som inte hade en fast arbetsplats uttryckte sin villighet att hitta ett arbete. Detta var deras innerligaste framtidsönskemål och det framgår även av det följande intervjuexemplet:

\footnotetext{
Många invandrare går bara och städar och är nöjda eftersom de har arbete, de kan själva [försörja] sig, det vill säga de behöver inte gå till FPA [socialskyddet] eller någon annanstans. De har egen lön ... Även om många tycks tro att invandrarna inte vill arbeta. I början vill alla arbeta, men när det är alltför svårt i Finland.

Många är tvungna att gå hemma många många många år. (En kvinna som har flyttat till Finland från Östeuropa)
}

Tvärtemot den infödda befolkningens fördomar ville intervjudeltagarna ha en arbetsplats i Finland, de ville ha arbete och inte bli beroende av socialskyddet. Enligt invandrarna säkrade en arbetsplats bättre utkomst för dem samt en viss status på arbetsplatsen och i andra sociala grupper. Grupper som hade svårt att få sysselsättning i Finland nekades arbetarmedborgarskap. Dessa observationer stödjer Frasers (1997) påstående att systemen gör dem som inte har fått erkännande till sämre lottade och sämre respekterade individer. Den orättvisa fördelningen av materiella resurser har även lett till social orättvisa (Fraser, 1997).

Social uppskattning märks som jämlika möjligheter för alla, även för representanter för minoriteter genom att hänsyn tas till deras olika utgångspunkter - till exempel språk, religion, ras och klass. Utgångspunkten för jämlikt erkännande är medvetenhet om multikulturalism och pluralism. Geografiskt begränsas inte heller finländskt medborgarskap bara till Finlands gränser. Finländare har fötts i många länders kulturella och språkliga miljöer, så som nästa intervjuobjekt uttrycker det: 
Invandrarnas yrkesutbildning och sysselsättning i Finland

\begin{abstract}
Alla talade finska hemma. Vi hade fått en sådan fostran att det är vårt modersmål och att det är vårt hemspråk. Och man ska tala och kunna det. Vi respekterade detta vårt eget modersmål och även jag när min son föddes, ... jag talade alltid finska med honom. Och min son bor nu också här [i Finland]. Han är mig nu mycket tacksam för att "du var en bra mamma när du lärde mig finska språket". Att det liksom kom via mamma det finska språket... När jag kom till Finland blev jag förvånad när vissa sade, att de försöker säga till mig, säkert på grund av accenten... att du är rysk. Jag sade att hör ni, jag är finländsk. Det höll jag fast vid hela tiden i Ryssland. Och inte har jag något mot ryssar. Självklart respekterar jag dem. Även min man är rysk och allt. Men de prackar det på mig [här Finland]. Jag blir alltid förvånad, att hur kan människor vara så oförskämda att någon bestämmer för någon annan vad den är. Jag känner ju mig som finländare. Varför måste jag, någon vill att jag ska säga att "jo, här är jag rysk"? (Språklärare, kvinna, ingermanfinländare)
\end{abstract}

Efter att ha flyttat till Finland upplevde intervjuobjektet en stark konflikt i de infödda finländarnas förhållningssätt till hennes finländska identitet som hon måste slåss för i sitt fosterland. Idén i Honneths $(1992,1995)$ normativa erkännandeteori är att skapa en personlig identitet och att utvecklas som person. Psykologiska resurser är självtillit, självrespekt och självaktning som bildas i interaktion med omgivningen. Social respekt bygger på erkännandemönster i relation till dessa aspekter. Honneths (2004) erkännande har en klart subjektiv, icke-kommersiell, psykologisk och kulturell karaktär. Det är sårande när erkännande nekas eftersom det skadar subjekten och begränsar deras frihet att agera och förstå sig själva. Honneths synsätt innehåller även ett normativt ideal eftersom han påstår att erkännande inte bara är abstrakt rättvisa och jämlikhet, utan också personlig utveckling, en överenskommen mental atmosfär i en viss livsvärld och "ett bra liv" (Honneth, 1995, s. 172). Invandring är förenad med mångahanda press och stressfaktorer, så som nästa intervjuobjekt uttrycker det:

Min man beslutade att han också kommer hit till Finland. Men det var en så påfrestande erfarenhet för honom ... kurserna i finska. Allt var för honom fruktansvärt förnedrande. Han var en namnkunnig lärare och hade undervisat många generationer, en sådan som var riktigt respekterad och redan grå... Och sedan när han hamnade här på kurs, där man förhåller sig på ett annat sätt. Människor har sina egna vanor, och när det var något prov i finska. Så är han van att man tar en vit pappersremsa för då börjar hans tanke löpa. Och finska språket är ju förfärligt svårt, trots att han kan språk, eftersom han är lingvist till yrket. Han sade att finska är ett alldeles speciellt språk. Att det är bara att lära sig utantill... Och när det finns 10 undantag till reglerna. Så han tog ett sådant vitt papper och började sedan skriva det där provet. Och den unga läraren där gjorde så här [ryckte bort pappret]... Den där unga läraren visste att han är lärare och tillät aldrig att någon fuskade. Den etiken är trots allt det viktigaste för oss. Han har gjort allt, doktorsavhandlingar och allt. Och sist och slutligen gick han tre år på kursen och fick sedan också den tredje nivån men sedan fick han dessutom magsår... [Läraren] tänkte att någon ryss där börjar fuska nu. Jag vet inte, kanske tänkte han inte så heller, men att behandla en äldre människa respektlöst... Och han var så samvetsgrann också. Men nu undervisar han [i den tidigare hemstaden], fick inte arbete i Finland. Det 
borde vara riktigt bra finska. Han fick en sådan bild att det ska vara riktigt, du vet super super... (Före detta språklärare, i Finland skolbiträde, kvinna)

Intervjupersonens man upplevde en konflikt i finsklärarens attityd till honom, eftersom den kränkte hans moraliska och yrkesmässiga identitet. Trots att han själv var professor i lingvistik fick han ingen klar uppfattning om vad som är en tillräckligt bra nivå i finska språket. Erkännande av tidigare utbildning gällande invandrare regleras på officiell nivå bland annat av Utbildningsstyrelsen. I praktiken är erkännandet av tidigare inhämtade kunskaper mycket oenhetligt och på många håll är även yrkesutbildade personer tvungna att börja om sina studier från början i Finland. Jaakkolas och Reuters undersökning om sysselsättningen hos invandrarkvinnor från det forna Sovjetunionen visade att inte ens en högskoleexamen avlagd i ursprungslandet garanterade sysselsättning. Däremot underlättades anställning av en utbildning som skaffats i Finland. En högskoleexamen avlagd i ursprungslandet verkade vara till störst nytta för kvinnor som bott längre, över 10 år, i landet (Jaakkola \& Reuter, 2007).

I moraliskt och etiskt avseende filtreras erkännande genom olika socialgruppers sammanflätade representationsstrukturer. De härskande kärngrupperna utformar sina hierarkiska statusnivåer som håller de underställda grupperna som beroende och irrationella - rentav odugliga medborgare. Respektlöshetens språk existerar i "andra", uteslutna gruppers jagbild och inbördes relationer samt i det normativa språket hos "riktiga medborgare" i det demokratiska samhället. Att nå status och erkännande är komplicerat: det fås inte med verbala krav eftersom det är att stiga in i diskursen hos maktgruppen i det offentliga livet. I det sistvalda intervjuexemplet berättar en person hur arbetsgivarna uppskattade utbildning skaffad i Finland högre.

\footnotetext{
I Finland uppskattas utbildning avlagd i Finland allra högst. ... Man misstänker eller tar inte invandrare på allvar. ... Vi tror att det som ges här [i Finland], det [utbildning] är bäst. Inte stämmer det. Det är klart, ... människors hjärnor fungerar precis på samma sätt även på andra ställen (med ett skratt). De här fördomarna att jag säger ibland till exempel att ta tjänstemän [i arbete]. Man vill ta 20 eller 30 finländare ... och en invandrare. Finländare tas lättare. Och en invandrare, det att ta honom/henne i arbete är komplicerat. Och om vi sedan tar, ska det göras ett stort nummer av det, att vi har en invandrare anställd. (Man som flyttade till Finland från Mellanöstern)
}

Många invandrare sökte sig på nytt till utbildning i Finland för att förvissa sig om en arbetsplats i framtiden. Personer som var högutbildade i ursprungslandet sökte sig till en utbildningsnivå under sina förutsättningar i Finland. Till exempel en kvinna, som hade avlagt ekonomexamen och arbetat med ledning på mellannivå, sökte till yrkesinriktad vuxenutbildning för att skaffa sig en bokförarexamen. Därefter fick hon också en anställning som bokförare i ett finländskt företag. Dessförinnan var hon anställd i en städfirma i nästan fem år. 
Resultaten av både enkäten och intervjun visade att erkännandet och accepterandet av invandrare är förknippat med utmaningar av många slag. Invandrarna utmanar arbetsplatserna och läroinrättningarna att granska avvikelse från det finländska, eller förmågan att tolerera olikhet. Arbetsgivarna kan utveckla mer multikulturella rekryteringsrutiner för att sysselsätta invandrare. Även utbildningsorganisationerna har relativt fria händer att skapa nya rutiner för erkännande. Många enkätdeltagare hade deltagit i såväl olika praktikperioder som många utbildningar, varav yrkesinriktad utbildning var mest populär.

\section{Övergång från en utbildning till en annan för ungdomar med olika kulturell bakgrund}

Ungdomarna beskrev många olika övergångar: flyttar från ett land till ett annat, byten mellan skolor och inom skolan, övergångar mellan skola och arbetsliv samt övergångar efter utbildning. Ungdomarna beskrev sin egen eller sin familjs flytt före ankomsten till Finland via något annat land, flytten till Finland samt från en ort till en annan i Finland. Dessutom övervägde de att flytta från Finland: "Inte har jag några planer än om jag ska bli kvar här. Jag ska se nu hur det går, om det är krig där i mitt eget land eller inte. Det här är ett lugnt land, här är bra att vara. Men om kriget upphör så det är klart, alla har ett eget hemland" (N1) ${ }^{1}$. Exemplet återspeglar osäkerhet i fråga om flytt och nylokalisering beroende på krigsläget i ursprungslandet samt multilokalitet (se Haikkola, 2012; Hviid \& Zittoun, 2008). Ungdomarnas funderingar återspeglar även övergång fram och tillbaka och dialektik: å ena sidan är man "här" men å andra sidan kan man även åka till "hemlandet". Den stora frågan är "Men om".

I myndighetsrepresentanternas svar identifierades sex temaområden som var bundna - antingen hindrande eller främjande - till ungdomarnas övergångar från den grundläggande utbildningen till yrkesutbildning. De framkom även i intervjuerna med ungdomarna. Temaområdena var följande: språkliga och självupplevda, utbildningsmässiga och strukturella samt sociala och kulturella övergångsfaktorer. De språkliga faktorerna bestod närmast av kunskaper i finska språket. Till de utbildningsmässiga faktorerna räknades skolans interna frågor gällande undervisning och handledning och till de sociala frågorna i sin tur vänner och familj. De kulturella övergångsfaktorerna refererade till kulturella skillnader, och de sociala åter till systemet och strukturerna samt till tjänster riktade till ungdomar. Med självupplevda övergångsfaktorer hänvisade myndighetsrepresentanterna till den studerandes motivation, kunskaper samt hans eller hennes livssituation eller livshistoria.

Uppmärksamheten fastnar på att myndighetsrepresentanterna upprepade samma saker. Flest omnämnanden kom från det språkliga och strukturella tema- 
området och minst från det kulturella temaområdet. Även om de båda gruppernas omnämnanden inte kan jämföras direkt med varandra är en granskning av dessa två perspektiv intressant och kompletterar dem eftersom båda grupperna verkar inom samma område. Myndighetsrepresentanterna ombads nämna faktorer som de ansåg påverka skolövergången, medan ungdomarna berättade mer fritt om sin egen utbildningsväg. Ungdomarna förde fram flest omnämnanden om sociala faktorer. Dessutom nämnde ungdomarna färre omständigheter som gällde språkliga faktorer, medan det för myndighetsrepresentanterna var en av de viktigaste faktorerna. Ungdomarna förde även fram två omständigheter som myndighetsrepresentanterna inte nämnde alls: en anställning påverkas av sökandens utländska bakgrund och ansökan till utbildning av att skolan ligger på ett besvärligt ställe. Visserligen nämnde ett antal myndighetsrepresentanter attityder som en omständighet som påverkar övergångar. Detta kan tolkas som att attityder ansågs höra samman med olika förhållningssätt till ungdomar.

Som egna personliga faktorer nämnde ungdomarna sin historia, sina färdigheter och kunskaper samt språkkunskaper. I följande exempel beskriver en ungdom sin egen övergång mellan grundskolan och gymnasiet som ångestfull.

\begin{abstract}
Egentligen är jag inte här nu, att gymnasiet. Gymnasiet verkade ganska intressant, har själv på något sätt analyserat att jag ska gå i gymnasiet. När jag gick i högstadiet tyckte jag att jag var en mönsterelev. Men sedan började jag i något skede oroa mig för övergången mellan årskurs nio och gymnasiet. Och sedan fortsatte det hela gymnasietiden och på något sätt blev studierna sedan lidande. För att återgå till frågan är det kanske så att det som inte har blivit klart är kanske just det här gymnasiet. Att om jag hade tagit det mer på allvar, men jag kunde aldrig förhålla mig riktigt allvarligt till det. (N9)
\end{abstract}

En studiehandledare som arbetar i grundskolan fäste däremot uppmärksamhet på ungdomarnas bild av deras eget lärande och deras egna färdigheter: "Dessutom har många elever med ett annat språk en orealistisk bild av deras eget lärande och färdigheter (T4). De personliga faktorerna återspeglade ungdomarnas individuella erfarenheter, tankar och val i anslutning till deras utbildningsväg. $\AA$ ena sidan kan ungdomarnas funderingar även beskrivas med Salmela-Aros (2008) modell 4S om hur ungdomarna tar riktning, orienterar, justerar och anpassar sig i övergångarna. För ungdomen i exemplet medförde rollövergången från "mönsterelev" i grundskolan till gymnasiet problem och hen blev tvungen att rikta om sin studieväg på ett nytt sätt. $\AA$ andra sidan återspeglar den ungas funderingar den utveckling och förändring som skolövergången och gymnasietiden medförde och som ledde till att gymnasiestudierna avbröts.

Språkliga faktorer var en av de av myndighetsrepresentanterna oftast nämnda övergångsfaktorerna. Man skulle kunna säga att detta upprepades som ett mantra. "Kunskaper i finska är avgörande för inträde till skolor. För alla med ett annat språk ordnas ett språktest (skriftlig del och intervju). På basis av dessa resultat fattas beslut - antagning till gymnasium eller yrkesskola eller inte." (T5) 
Ungdomarna nämnde detta närmast i början av en utbildning: "I början var nog just det besvärligt, att man inte kunde språket alls, att det gav problem." (N10) Språkkunskap och vilken betydelse den har för invandrarnas integration har även undersökts i Finland ända sedan slutet av 1980-talet (Latomaa m.fl., 2013, s. 164-165). Det faktum att språkkunskap även i detta material samlar flest omnämnanden är överraskande därför att en del av ungdomarna har gått hela grundskolan i Finland. Man får fundera om kunskaper eller snarare brist på kunskaper i språk är något av en självklarhet som automatiskt tilldelas ungdomar med invandringsbakgrund. Döljer det fördomsliknande antagandet andra omständigheter som till exempel inlärningssvårigheter?

Stöd och vägledning från vänner och familj är ytterst viktiga för ungdomar. Familjens integration och dess resurser är en viktig omständighet $i$ ungdomarnas liv och även i deras studieframgång (Teräs, 2012; Teräs \& Kilpi-Jakonen, 2013). Säävälä (2013) har träffande konstaterat att man i forskning om flyttningsrörelsen har varit benägen att vidmakthålla individuella uppfattningar om flyttning som självklara. Emellertid borde en avsevärd del av flyttningsrörelsen granskas som familjeprojekt: flytten påverkar ofta hela familjens och släktens välfärd och möjligheter.

Till övergångsfaktorer som gäller gemenskap räknades även kulturella faktorer. En studiehandledare i grundskolan konstaterade kortfattat: "kulturen i hemmet" (T7), som svar på frågan vad som hindrar eller främjar ungdomarnas övergångar. En annan lärare i ett yrkesinstitut framlade åldersrelaterade svårigheter och kulturella konflikter i ungdomarnas liv. "Besluten är oftast extremt svåra och även sporadiska i 15-årsåldern när även en tid med kulturella konflikter på flera plan ofta råder i den ungas liv" (T8). Alitolppa-Niitamo (2003) har beskrivit denna period av konflikter via två samtidiga övergångar: egen utveckling och därmed relaterade frågor samt frågor som gäller samhället. Ungdomarna själva nämnde inte kulturella faktorer direkt, men en av dem beskrev hur utlänningskap kunde vara ett hinder att få arbete:

\footnotetext{
N1: Åtminstone har de [syftar på sina vänner med utländsk bakgrund] sagt till mig en gång att det är onödigt för oss att studera när vi är utlänningar. Vi får ändå inte något bra arbete. Vår framtid är någon pizzeria eller något sådant.

Intervjuaren: De tror att det beror på att de är utlänningar att de inte får arbete? N1: Nå mer eller mindre jo.
}

Även en studiehandledare som arbetar som specialklasslärare nämnde som en aspekt "fördomar hos lärare i gymnasium och i yrkesskola" (T6). Attityderna och fördomarna gentemot invandrare samt den diskriminering de upplever kan försämra deras välfärd och hindra deras integration i det finländska samhället (Liebkind m.fl., 2004, s. 279). Diskrimineringen som upplevs i övergångarna kan vara mycket sårande eftersom ungdomarna då också söker sin egen väg och speglar sig mot sina kamratgrupper. 


\section{Sammanfattning}

Många tidigare forskningsresultat (t.ex. Heath \& Cheung, 2007) har avslöjat att invandrare från länder utanför den Europeiska unionen, från s.k. tredjeländer, har svårigheter att få en arbetsplats som motsvarar deras kompetens trots deras utbildning och kvalifikationer. Det kan också påstås att dessa nya medborgare behandlas orättvist. Finland, liksom andra länder i den Europeiska unionen, har en utmaning $i$ att driva sin jämställdhetspolitik även bland nyinflyttade. Ett meningsfullt arbete främjar integrationen i ett nytt land. Och den infödda befolkningen integreras bäst med nya kulturer och personer med olika kulturell bakgrund genom interaktion.

Resultaten som gäller ungdomar visade att ungdomar med olika språk- och kulturbakgrund beskrev många slags övergångar: att flytta till Finland, att börja skolan, att byta skola och att övergå från skolan till arbetslivet. Särskilt ungdomarnas sociala relationer till vänner och familjer framstod som viktiga i ungdomarnas tal. Utbildningsvägen gick inte nödvändigtvis som en rak linje från ett skolstadium till ett annat och vidare ut i arbetslivet. Detta beskrev Lindberg (2008) som icke-traditionella övergångar. Anmärkningsvärt är att utbildningsvägarna ur ungdomarnas perspektiv visade sig osammanhängande och omlokaliseringar var typiska (jfr Hviid \& Zittoun, 2008). Salmela-Aro (2008) kallar detta anpassning i en situation där den ungas önskemål och förväntningar, exempelvis gällande skolplats, inte uppfylldes och hen blir tvungen att omvärdera situationen. Haikkola (2012) kallar det däremot för multilokalitet hos ungdomar med invandringsbakgrund.

Ungdomarna samt de myndighetsrepresentanter som arbetar med dem pratade om övergångsfaktorer av sex slag: språkliga, självupplevda, strukturella, utbildningsmässiga, sociala och kulturella. Vi förenade dem till tre helheter på olika nivå: individuella faktorer, gemenskapsfaktorer och samhällsfaktorer som interagerar sinsemellan och som även förenar materialen som gäller vuxna och ungdomar. Beaktansvärt är att språkkunskaper upprepas. Man kan även fråga sig om språkkunskaper döljer något annat och om det är en typisk reaktion i bemötandet av personer med en annan språklig och kulturell bakgrund. Å andra sidan kanske upprepningen av strukturella faktorer i myndighetsrepresentanternas svar återspeglar deras maktlöshet och att enskilda personer upplever att de inte kan påverka situationen.

Invandring och migration är förenade med en inbördes rörelse där processer som gäller individer, grupper och samhälle samt globalisering flätas samman. Vid forskning om dessa företeelser behövs därför olika tillvägagångssätt och begrepp för att förstå och analysera olika sidor av företeelsen. Utgångspunkten för jämlikt erkännande är medvetenhet om multikulturalism och pluralism. Men å andra sidan räcker inte enbart medvetenhet om det inte också finns praktiska handlingar där en person inte behandlas nonchalant eller rentav avvisande. För 
Invandrarnas yrkesutbildning och sysselsättning i Finland

individen är erfarenheten av invandring ofta konfliktfylld när hen upplever hur hens livs- och yrkesförhållanden har förändrats. På organisationsnivå innehar däremot erkännande av kompetens, yrkeslärande och avancemang i karriären en nyckelposition. Integration står för en samhällelig, även global, dimension i forskningen om invandring och migration och för sin del en transformation när det gäller personers och organisationers yrkeslärande och erfarenheter i en ny kulturell omgivning.

\section{Slutnot}

${ }^{1} \mathrm{~N}=$ en ungdom, $\mathrm{T}=$ en myndighetsrepresentant, siffrorna betyder individuella personer.

\section{Om författarna}

Johanna Lasonen är Professor Emerita på Department of Leadership, Counseling, Adult, Career and Higher Education (LCACHE), College of Education, University of South Florida, USA. Hennes forskningsintressen fokuserar på invandrares tillgång till arbete, jämförande yrkesutbildning, bedömning av yrkesutbildningsprogram och jämställdhetsfrågor inom utbildning och arbetskraft.

Marianne Teräs är docent och medledare för forskargruppen Yrkesutbildning (VETYL) vid Institutionen för Pedagogik och Didaktik, Stockholms universitet. Hennes forskningsintresse fokuserar på yrkesutbildning, lärande inom vård- och omsorg och migration i relation till yrkesutbildning. Hon leder för närvarande forskningsprojektet "Integration och inkludering av migranter i och genom yrke och arbete" finansierat av FORTE - Forskningsrådet för hälsa, arbetsliv och välfärd.

Carine Cools, doktor, har arbetat som forskare vid Jyväskylä universitet, Finland. Hennes speciella intressen har varit kvinnliga invandrare, språkinlärning och kommunikation på mångkulturella arbetsplatser. 


\section{Referenser}

Alitolppa-Niitamo, A. (2003). Liminaalista jäsenyyteen: Somalinkielisten nuorten siirtymien haasteita [Från liminal till medlemskap: Utmaningar för övergången för somalisktalande ungdomar]. I P. Harinen (Red.), Kamppailuja jäsenyyksistä etnisyys, kulttuuri ja kansalaisuus nuorten arjessa (s. 17-32). Nuorisotutkimusverkosto, Nuorisotutkimusseura.

Braun, V. \& Clarke, V. (2006). Using thematic analysis in psychology. Qualitative Research in Psychology, 3(2), 77-101.

CEDEFOP (The European Centre for Development on Vocational Training). (2008). Terminology of education and training policy: A multi-lingual glossary [Terminologi för utbildning och utbildningspolitik: En flerspråkig ordlista]. Office of Official Publications of the European Union.

Eurostat. (2020a). Migrant integration statistics - labour market indicators [Statistik över migrationsintegration - indikatorer på arbetsmarknaden]. https:/ /ec.europa.eu/eurostat/statistics-explained/index.php?title=Migrant_integration_statistics_\%E2\%80\%93_labour_market_indicators

Eurostat. (2020b). Unemployment by gender [Arbetslöshet efter kön]. https://ec.europa.eu/eurostat/statistics-explained/index.php?title=Unemployment_statistics\#Unemployment_by_gender

Fraser, N. (1997). Justice interrupts: Critical reflections on the "postsocialist" conditions [Rättvisa avbryter: Kritiska reflektioner över "postsocialistiska" villkor]. Routledge.

Guest, G., MacQueen, K.M. \& Namey, E.E. (2012). Applied thematic analysis [Tillämpad tematisk analys]. SAGE.

Haikkola, L. (2012). Monipaikkainen nuoruus: Toinen sukupolvi, transnationaalisuus ja identiteetit [Multilokal ungdom: Andra generationen, transnationalitet och identiteter]. (Sosiaalitieteiden laitoksen julkaisuja 2012: 15). Helsingin yliopisto, Sosiaalitieteiden laitos.

Heath, A. \& Cheung, S.Y. (2007). Unequal chances: Ethnic minorities in Western labour markets [Ojämna chanser: Etniska minoriteter på västerländska arbetsmarknader]. Oxford University Press.

Heath, A., Rothon, C. \& Kilpi, E. (2008). The second generation in Western Europe: Education, unemployment, and occupational attainment [Den andra generationen i Västeuropa: Utbildning, arbetslöshet och yrkesutbildning]. Annual Review of Sociology, 34(1), 211-235.

Helsingfors stads faktacentral.(2013). Helsingin ulkomaalaisväestö vuonna 2013 [Utländsk population i Helsingfors år 2013]. Tilastoja 31/2013. Helsingin kaupunki.

Justitieministeriet. Lag om främjande av integration. (1386/2010).

Honneth, A. (1992). Integrity and disrespect: Principles of a conception of morality based on the theory of recognition [Integritet och respektlöshet: Principer 
för en moralisk uppfattning baserad på teorin om erkännande]. Political Theory, 20(2), 187-201.

Honneth, A. (1995). Patterns of intersubjective recognition: Love, rights, and solidarity [Mönster av intersubjektiv erkännande: Kärlek, rättigheter och solidaritet]. I A. Honneth (Red.), The struggle for recognition: The moral grammar of social conflicts (s. 92-130). Polity Press.

Honneth, A. (2004). Recognition and justice [Erkännande och rättvisa]. Acta Sociologica, 47(4), 351-364. doi: 10. 1177/0001699304048668

Hviid, P. \& Zittoun, T. (2008). Editorial introduction: Transitions in the process of education [Redaktionell introduktion: Övergångar i utbildningsprocessen]. European Journal of Psychology of Education 23(2), 121-130.

Jaakkola, M. \& Reuter, A. (2007). Maahanmuuttajanaiset entisen Neuvostoliiton alueelta: Resurssit ja sijoittuminen työmarkkinoille [Invandrarkvinnor från före detta Sovjetunionen: Resurser och rankning]. I T. Martikainen \& M. Tiilikainen (Red.), Maahanmuuttajanaiset: Kotoutuminen, perhe ja työ (s. 335-358). Väestöliitto.

Kilpi, E. (2010). Toinen sukupolvi peruskoulun päättyessä ja toisen asteen koulutuksessa [Den andra generationen på slutet av grundskolan och på gymnasiet]. I T. Martikainen \& L. Haikkola (Red.), Maahanmuutto ja sukupolvet (s. 110132). Suomalaisen Kirjallisuuden Seura.

Kilpinen. J. \& Salonen, M. (2011). Maahanmuuttajien ammatillisen peruskoulutuksen tila lukuvuonna 2009-2010 [Läget för studerande med invandrarbakgrund inom den grundläggande yrkesutbildningen läsåret 2009-2010]. Koulutuksen seurantaraportti 2011/3. Utbildningsstyrelsen.

Kuusela, J., Etelälahti, A., Hagman, Å., Hievanen, R., Karppinen, K., Nissilä, L., Rönnberg, U. \& Siniharju, M. (2008). Maahanmuuttajaoppilaat ja koulutus - Tutkimus oppimistuloksista, koulutusvalinnoista ja työllistymisestä [Invandrarelever och utbildning - Forskning om lärandemål, utbildningsval och sysselsättning]. Opetushallitus.

Lasonen, J. (2009). Tavoitteena tunnustuksen antamisen tasavertaisuus [Syftet att ge likvärdighet i erkännande]. I J. Lasonen \& M. Halonen (Red.), Kulttuurienvälinen osaaminen koulutuksessa ja työelämässä (s. 145-153). FERA (Finnish Education Research Association).

Lasonen, J. (2010). Multiculturalism in the Nordic countries [Multikulturalism i de nordiska länderna]. I C. Grand \& A. Portera (Red.), Intercultural and multicultural education: Enhancing global interconnectedness (s. 261-278). Routledge, Taylor \& Francis.

Lasonen, J., Cools, C. \& Teräs, M. (2011). Migrant women's access to education and work: A Finnish case reflected with European research literature [Invandrarkvinnors tillgång till utbildning och arbete: Ett finskt fall som återspeglas i europeisk forskningslitteratur]. ECER Conference presentation. Berlin/Germany, September 2011. 
Latomaa, S., Pöyhönen, S., Suni, M. \& Tarnanen, M. (2013). Kielikysymykset muuttoliikkeessä [Språkfrågor i migration]. I T. Martikainen, P. Saukkonen \& M. Säävälä (Red.), Muuttajat: Kansainvälinen muuttoliike ja suomalainen yhteiskunta (s. 163-183). Gaudeamus.

Liebkind, K., Mannila, S., Jasinskaja-Lahti, I., Jaakkola, M., Kyntäjä, E. \& Reuter, A. (Red.) (2004). Venäläinen, virolainen, suomalainen: Kolmen maahanmuuttajaryhmän kotoutuminen Suomeen [Ryska, estniska, finska: Integrering av tre invandrargrupper i Finland]. Gaudeamus.

Lindberg, M.E. (2008). Higher education-to-work transitions in the knowledge society: The initial transition and positional competition point of view [Övergångar från högre utbildning till arbete i kunskapssamhället: Den inledande övergången och positionell konkurrenssynpunkt]. Higher Education in Europe, 33(4), 375-385.

Martikainen, T., Saari, M. \& Korkiasaari, J. (2013). Kansainväliset muuttoliikkeet ja Suomi [Internationella migration och Finland]. I T. Martikainen, P. Saukkonen \& M. Säävälä (Red.), Muuttajat: Kansainvälinen muuttoliike ja suomalainen yhteiskunta (s. 23-54). Gaudeamus.

Rumbaut, R. (2007). Ages, life stages, and generational cohorts [Åldrar, livsstadier och generationskohorter]. I A. Portes \& J. DeWind (Red.), Rethinking migration: New theoretical and empirical perspectives (s. 342-387). Berghahn Books.

Ruotsalainen, K. \& Nieminen, J. (2012). Toisen polven maahanmuuttajia vielä vähän Suomessa [Det finns några andra generationens invandrare i Finland]. Hämtad 12 mars 2015 från http://www.stat.fi/artikkelit/2012/art_2012-0704_003.html?s=0

Salmela-Aro, K. (2008). Motivaatio ja hyvinvointi elämän siirtymissä [Motivation och värmående i livets övergångar]. Psykologia, 43(5), 374-379.

Schuster, A., Desiderio, M.V. \& Urso, G. (2013). Recognition of qualifications and competences of migrants [Erkännande av migranternas kvalifikationer och kompetenser]. International Organization for Migration. Hämtad 10 april 2015 från http:/ / www.migrantwomennetwork.org/IMG/pdf/ENoMW_and_EWL_Research_Study_Migrant_Women_s_Access_to_Labourmarket_March_2012.pdf

Statistikcentralen. (2020). Suomi lukuina 2020 [Finland i siffror 2020]. Hämtad från http:// www.stat.fi/tup/julkaisut/tiedostot/julkaisuluettelo/yyti_sul_202000_2020_23212_net.pdf

Säävälä, M. (2013). Maahanmuutto perheilmiönä [Invandring som familjfenomen]. I T. Martikainen, P. Saukkonen \& M. Säävälä (Red.), Muuttajat: Kansainvälinen muuttoliike ja suomalainen yhteiskunta (s. 101-122). Gaudeamus.

Taylor, C. (1994). The politics of recognition [Politik för erkännande]. I A. Gutmann (Red.), Multiculturalism and the politics of recognition (s. 25-73). Princeton University Press. 
Invandrarnas yrkesutbildning och sysselsättning i Finland

Teräs, M. (2012). Intercultural space as transitional space: Movements, transformations and dialectical relations [Interkulturellt utrymme som övergångsrum: Rörelser, transformationer och dialektiska relationer]. Research in Comparative and International Education, 7(4), 503-513.

Teräs, M. \& Kilpi-Jakonen, E. (2013). Maahanmuuttajien lapset ja koulutus [Invandrares barn och utbildning]. I T. Martikainen, P. Saukkonen \& M. Säävälä (Red.), Muuttajat: Kansainvälinen muuttoliike ja suomalainen yhteiskunta (s. 184202). Gaudeamus. 